\title{
Chapter 12 \\ The Ethics of Interconnectedness: Charles Taylor, No-Self, and Buddhism
}

\author{
Ashwani Peetush
}

\subsection{Introduction}

My aim in this paper is to chart what I see as parallels between the ontology of self in Charles Taylor's work and that of various Buddhist 'no-self' views, along with parallels between Taylor's commitment to reviving republican ideas (in a 'communitarian' form) and some aspects of Buddhist ethics. I see key resemblances and overlaps at the level of metaphysics as well as ethics. For Taylor, the sorts of atomistic accounts of self that have come to be accepted as natural and unquestionable in the West are deeply misguided. The dominant Hobbesian-Lockean procedural picture of selfhood blinds us to the intrinsic relatedness of self to others and has profoundly negative consequences for the kinds of shared conceptions of the good necessary for viable and functioning democracies to survive and flourish. For Taylor, we thus need to retrieve and rearticulate a more accurate understanding of the self (Taylor 1985a, c, d, 1989, 1995a, b, 2003). This conception acknowledges that the self is located in a web of locution, conversation, and social interconnectedness, a sense that gives rise to an expanded notion of our moral and political duties. I argue that such an understanding of the self and ethics has strong resemblances to the kinds of views of the self and ethics as articulated by various schools of Buddhism. Conceptions of anātman or no-self and pratītya-samutpāda (interconnectedness) similarly broaden the scope and domain of our moral concern to be more inclusive by interrogating perspectives that conceive of the self as a separate and isolated individual. This is illustrated by, for example, the Dalai Lama (1999),

I would like to thank Gordon Davis, Steven Thompson, Kathy Behrendt, Nigel DeSouza, Rebekah Johnston, Gary Foster, Renato Cristi, Emily Jull, John Abraham, Christopher F. J. Ross, and Angela Brown for sharing their insight and their helpful suggestions; of course, all shortcomings are my own.

A. Peetush $(\square)$

Wilfrid Laurier University, Waterloo, ON, Canada

e-mail: apeetush@wlu.ca 
who argues that a more accurate understanding of the self as empty of inherent and separate existence leads to adopting a more compassionate ethical stance towards others. I would suggest that, along the same lines, this understanding is required for a sustainable future for not only our communities, but that of an increasingly interrelated and inter-dependent world.

Indeed, this is not simply a matter of abstract theoretical concern, but of daily practice: how we see the other affects how we treat them. If there is anything to be learned from the 2008 global financial crisis, it is that an ethic rooted in a metaphysics of the self as an individual rational agent, seeking to contract with adversarial others for the sake of maximization of individual self-interest, has potentially devastating consequences for democracy and global equality. A constellation of current movements in the West, including Taylor's communitarian republicanism, deep ecology, feminism, and race theory, boldly challenge the distortion of narrow and truncated moralities to which individualistic ontologies of the self lead. These contemporary challenges in Western philosophies have deep resonances with a variety of Buddhist views. The chorus of these perspectives seek to show that a more perspicuous understanding of the self as part and parcel of a multi-faceted web of interrelation of self to other guides us to see that the interests of others are indeed our own interests, and to see their suffering as our own suffering. Ontologies of interconnectedness of self to other thus widen the range and depth of our ethical and moral concerns.

To be sure, I understand that there are profound differences between Taylor's view of the self and those of various Buddhist schools (and among Buddhist schools themselves); nevertheless, despite such divergences, I see common ground in their emphasis on an ontology of interconnectedness of self and other, and, in particular, the ethical, social, and political implications of this interconnectedness of self to other. This is, in broad strokes, the purpose and focus of this chapter: to map out some of these overlaps of insight and understanding.

\subsection{The Punctual Self of Procedural Liberalism ${ }^{1}$}

Taylor argues that the individualistic atomist ontological account of the self presupposed by modern Western liberal societies distorts our understanding of the nature of our interrelated being and is far from accurate, yet, it has become almost axiomatic, and its grip on the modern imagination nearly impossible to loosen. To begin to broaden one's understanding is to see its contingency and its history:

To come to live by this definition of the [self] - as we cannot fail to do, since it penetrates and rationalizes so many of the ways and practices of modern life - is to be transformed: to the point where we see this way of being as normal, as anchored in perennial human nature in the way our physical organs are. So we come to think that we 'have' selves as we have heads. But the very idea that we have or are 'a self', that human agency is essentially

\footnotetext{
${ }^{1}$ Regarding one possible confusion about the term 'punctual', see note 2 below.
} 
defined as 'the self', is a linguistic reflection of our modern understanding and the radical reflexivity it involves. Being deeply embedded in this understanding, we cannot but reach for this language; but it was not always so. (1989, 177; see also, 106)

The brand of liberalism from which this picture emerges, supported from leftist liberals, such as John Rawls (1999), to right-wing libertarians, such as Robert Nozick (1974), has its roots in Hobbes and Locke. This view sees society instrumentally: as a contract that individuals enter into with other individuals for the sake of their enlightened self-interest. Prior to society, such individuals exist in a "state of nature," in which there is no rule of law except that of power and violence where individuals are isolated selves in conditions of competition for scarce resources. Such a situation is inherently unstable: each uses his right of nature and is free to do whatever he wants whenever he wants to get whatever he wants, by whichever means necessary. Violence and coercion reign supreme. To get out of this situation, for Hobbes, individuals purportedly contract with adversarial others and agree to lay down their natural freedom to use force to achieve their ends, as long as other individuals are willing to do the same, and, as long as there is an authoritative party to secure the agreement. We strive together to achieve convergent ends that we could not alone, as our individual self-interests in stability and security intersect.

The legacy of this picture is difficult to underestimate, especially in economics and politics. The putative purpose of the modern liberal state has come to be seen as procedural, with equal and maximal facilitation of individuals' desire-fulfilment as the convergent goal of the state. Such a state is "neutral" with regard to the individual values of citizens, for any conception of an individual's good is seen as being as valid or as admissible (qua good) as any other. It makes no value judgements regarding either the individual good or the common good of the community. For these are both private matters on this conception of society (or in the case of communal goods, perhaps a family-based or association-level matter). A life of courage and compassion is treated as though it is as worthy as a life of consumerist egoism. For to distinguish between higher or lower, more worthy and less worthy, might be discriminatory and might jeopardize the freedom of individuals to choose for themselves whatever it is that they desire. Such distinctions would be an assault on the foundational value of a liberal society, which is the equal individual autonomy of each to decide for oneself where one stands on such questions of value.

In Rawls's terms: the right takes priority over the good; the job of society is to figure out how to arbitrate between conflicting views of comprehensive notions of the good life and what equality requires in such terms, not to evaluate such notions or to promote any particular good. To endorse any particular view would be favouritism and discriminatory, and the worry - perhaps taken to an obsessive extreme - is that views not endorsed with official status would not be treated with equal respect. Fairness in such a view consists in coming up with the right decision-making procedures, not the right decisions - for there are no real right decisions, apart from what individuals choose for their own purposes (Taylor 1985b, 1989, 1995a).

Taylor contends that there are many profound problems with this model of liberalism. Such a model is not viable or realistic for a functioning democratic republic, 
which requires an extended and robust sense of ethical and political participation from its citizens, and some conception of the need for occasional self-sacrifice - at least with respect to any democracy that can flourish. The above liberal model presupposes a number of questionable assumptions about the self and its relationship to others that unduly narrow the range of potentially valuable ethical and political options for modern societies (1995a).

Let me begin with what I see as a deep problem with the contractual model, and something I see Taylor's communitarian republicanism, and forms of deep ecology, feminism, and Buddhism, as attempting to overcome. A critical issue here is one of moral and political motivation, and regard for the well-being of others. One of the key attractions of the contractualist model is that it purports to show how our duties towards others can be derived from individual self-interest and desire for individual security alone: it is in my enlightened self-interest, on this view, to take into consideration the interests of others because ultimately it will be of benefit to me. But this source of strength is its very weakness.

To see this, consider the following. On this model, why should I refrain from harming you and taking your possessions? If I do this, I will eventually be caught and imprisoned. In the long run, if we both agree to keep our contracts, then our individual convergent interests in individual security and property will be achieved; so it makes sense to obey the laws, they are always, in the end, a benefit for me - at least in the long run. A classic problem remains, however. What if I can be sure that no one is looking? Hobbes in such circumstances thought that it was imprudent to break the law because you could only get away with it once or twice, but that eventually you would be caught; this is not worth the risk. This response is weak: if moral, ethical, legal, and political obligation is grounded in my self-interest, there are times when the risk of getting caught will be sufficiently low that abstaining would be foolish (on a Hobbesian criterion of rationality). As long as I am clever enough, then it is in my interest to do whatever it takes to gain advantage. This is not simply an abstract concern, but one with which we are only too familiar: the world financial crisis of 2008 showed something along these lines. If the 'common good' is conceived of as (or reduced to) a deal struck between merely convergent selfinterests, it would turn out to depend on everyone's simply calculating the risk of getting caught versus what they might gain from defecting from shared norms, undetected. What is in fact in my true interest is to deceive you, to convince you that it is in our mutual self-interest to obey the law, but stab you in the back when you are not looking, which is one way of describing attitudes that were pervasive on Wall Street in the period leading up to that crisis.

There are other dire problems, as Martha Nussbuam (2006) has pointed out, for such models: direct moral, ethical, and political obligation is only ever owed to those who are regarded as potentially threatening, given the adversarial nature of this view. The reason I am motivated to contract with you in the first place is because you present a threat to me, to my life, to my property, as I do to your life, liberty, and 
property. But what if you do not present a threat to me? What if you are too weak, too young, too old, mentally challenged, or disabled (let alone of non-human species)? I have no theoretical or practical reason to contract with you, and, hence no direct moral or political obligation to you. Any perspective that makes our ethical and political obligations to the weakest and most vulnerable in our society only derivative or optional (e.g., children are the children of an adversarial other - they are like property, to harm them is to harm their owner) is to distort the very nature of ethics.

Taylor argues that the kinds of deep ethical and political sacrifices that republican democratic regimes require of their citizens, including such sacrifices as paying taxes, following the rule of law, and being called on to protect and defend society, require a sense of belonging and attachment to our compatriots, to a common and shared good, that is not reducible to individual self-interest. Nor is the good of others dependent simply on my desiring or choosing it and nor - accordingly - should my respect for their dignity be so dependent. We need to distinguish between two senses of collective goods, what Taylor calls convergent goods (e.g., fire stations, a public policing system, paved roads) versus common or shared goods, such as friendship and republican citizenry. In the case of a commonly shared good, the value of the good sought can only be defined in relation to an $u s$, in our connectedness and relationship as an us, whereas in the case of a convergent good no such relationship is necessary. All that is required for the latter is a 'me', and a narrow sense of self-interest. In a despotic society the kinds of sacrifices required for a political regime can be extracted from the ruled (via the threat of imprisonment for non-compliance) whereas this cannot be so for any free democratic republican regime. Coercion has to be replaced with an internal sense of motivation for acting out of genuine regard for the other, community, and the polis:

This can only be a willing identification with the polis on the part of the citizens, a sense that the political institutions in which they live are an expression of themselves. The "laws" have to be seen as reflecting and entrenching their dignity as citizens, and hence to be in a sense extensions of themselves.. .. It transcends egoism in the sense that people are really attached to the common good, to general liberty. But it is quite unlike the apolitical attachment to universal principle that the stoics advocated or what is central to modern ethics or rule of law $(1995 \mathrm{a}, 187)$.

Any flourishing democratic regime requires bonds of trust between citizenry, an attachment to the good of others as citizens of the same historical and cultural community, as interconnected patriots. Such bonds of trust and loyalty seem to lose their justification on the contractual model where the whole structure is based on the individual self-interest and separateness of isolated selves. However, the "very definition" of a free republican political regime requires an exploration of relationships of identity and community, an expansion of our moral concerns that move us beyond the false image of the self as some kind of discrete and unchanging individual entity (1995a, 192). 


\subsection{The Self in Webs of Interlocution}

The critical problem for the contractual model of society, argues Taylor, is that it is grounded in an inherently problematic ontological account of the self. The self is understood as a sort of atom, analogous to a kind of extension-less point in space what Taylor calls the "punctual" self, that is, from punctum or sharp point (1989, 159-176). ${ }^{2}$ This ontological picture of the self originates from thinkers such as Descartes, Hobbes, and Locke. They take the self to be a separate, discrete, and essentialist entity with impermeable borders, that stands outside of the web of communal relationships, minimally defined by being self-conscious. A few Hobbesian reservations aside, this set of thinkers largely agreed on something along the lines of the res cogitans of Descartes, the thinking substance that can be defined in isolation from the physical body or the world $(1989,156)$. It is a self "unencumbered" by any constitutive purposes or meanings, an individual entity that exists prior to and apart from any bonds of community, to borrow Michael Sandel's phrase (1995). All life plans and goals are optional, matters of autonomous choice and desire, and thus such a self contracts for the sake of his individual interest, against those who potentially stand in his way. In fact, all judgments of value or worth, for the modern self, are a part of the purely subjective, projected onto an inherently valueless and disenchanted objective cosmos (Taylor 1989, 143-176). They are fabrications of the mind, colouring our understanding of an inherently objective, meaningless, and unordered universe. The primacy of rights and the value of individual autonomy and freedom take pride of place in this picture. It is alleged to be a distinct human trait to be able to fashion new identities and thereby create meaning within what is a meaningless world. In its ultimate and hyper-individualistic form, the self may aspire to become a Nietzschean übermensch by conquering others, by standing above and apart from the community and world. Taylor points out that this sense of the self has such a firm hold on the modern imagination that it seems self-evident, natural, and unquestionable.

Yet, there are deep problems with this view of the self. It is true that as a self, we are physically individuated in a body $(1989,112-113)$, but this individuation does not exhaust our sense of self or personhood. Physical individuation may differ, but selves are permeable and necessarily interconnected in frameworks of social meaning and significance. The atomist or punctual view of the self buries these in a silence of inarticulacy. The idea of an atomist self as a punctum that exists prior to society in some state of nature is not only a benign historical myth or some purely heuristic device; it distorts the very nature of our lives, being, and interconnectedness. The self, Taylor argues, cannot be properly understood without reference to the "web of interlocution" in which we exist: "One is a self only among other selves. A self can never be described without reference to those who surround it" $(1989,35)$.

\footnotetext{
${ }^{2}$ This is a different usage of 'punctual' than the one employed by Mark Siderits to spell out construal(s) of the no-self claim in Buddhism (a usage that is discussed above, in Chap. 5, by Gordon Davis and Mary Renaud).
} 
We are intrinsically related to the self of others in multifaceted and dialogical relationships of conversation. We cannot be selves apart from such a web of relationships.

This is the sense in which one cannot be a self on one's own. I am a self only in relation to certain interlocutors: in one way in relation to those conversational partners who were essential to my achieving self-definition; in another in relation to those who are now crucial to my continuing grasp of languages of self-understanding - and of course, these may overlap. A self exists only within what I call 'webs of interlocution' (1989, 36; see also 1985a, 267; 1995c, 25-26).

Taylor's account of the self as not merely exhausted by the idea of mere selfconsciousness draws, in part, on Aristotle's insight that the human being is a social and political animal (1985d, 189); that indeed, contra the atomistic thesis, a self cannot be properly understood in isolation from the community. That is, personhood requires being a part of rich frameworks of meaning and significance, which are only made possible in interrelation and conversation with a community of others. Indeed, a self could not develop its basic capacity for communication or acquire a language without being a part of a community of users. Using Wittgenstein's insight, Taylor argues that the transcendental conditions of learning and understanding a language require relating to others; this is necessary in coming to know that one's usage of a term, for example, is indeed correct $(1989,38)$. Without language and the rich vocabularies of expression for which it allows, self-understanding, frameworks of meaning, significance, and purpose cease for beings like us. Judgements of value about the right thing to do or what it is good to be, of what is higher or lower, better or worse, cannot be made. Indeed, the very ideals of freedom and equality require shared frameworks of meaning and significance in which these are shared goods for us, for which we must be willing to make sacrifices.

Such judgements of value provide the horizon of meaning and significance in which a person makes sense of her life; they provide independent standards by which one conceives of one's life as worthwhile. Taylor argues that such frameworks of "strong evaluation" are not contingent or subjective projections on our part, but that they are an intrinsic part of the inter-subjective/objective ontological furniture of the cosmos for beings like us (1989, 53-62; 2003). Indeed, selves and their actions can only be understood as located within a conceptual structure that links judgements of value to self-interpretation, within a teleological framework (contra behaviourism). That is, the self can only exist in relation to such a structure of questions about the nature of the good. The most urgent constellation of such values concerns "respect for life, integrity, and well-being, even flourishing, of others" $(1989,4)$; these are infringed upon in various authoritarian regimes where a person can be tortured, raped or murdered for merely criticising authority. The importance of human rights illustrates the necessity of coming to grips with rich frameworks of meaning and significance in providing justification for such basic rights. The egoist contractual model fails at the task of justification, both due to its conception of 'ego' and its conception of 'contract'.

This ontology of the self not only enlarges the circle of moral and ethical concern to our communities, but it goes beyond such parochial borders. Respect and 
recognition of cultural membership, against a background of normative pluralism, hold particular importance on Taylor's view, since such membership provides the rich language and the horizon of meaning and significance in which I locate myself and define who I am. The conditions of being a full agent or self require membership in a community, and these are some of the conditions that make possible the exercise of my autonomy and freedom (Taylor 1993, 53-54); such a horizon provides meaningful choices among which I can choose. This is why recognition and respect of diverse identities and pluralism in a liberal state is critical. As we have seen with the colonial and post-colonial treatment of indigenous peoples and other minorities, denial of such recognition and respect can often lead to real damage. Even when legal and formal obstacles to opportunities are removed, members of marginalized communities may simply be unable to take advantage of this due to internal hindrances caused by images of self-inferiority that they have come to adopt as a consequence of the structural domination that the majority has mirrored to them for centuries (Taylor 1995c, 225-227). But the modern self as punctum has a challenge in articulating such concerns, as it narrows the range of the ethical to the realm of formal equality and individual self-interest, thereby illegitimately limiting the scope and domain of ethical concern as a consequence of its distorted, inaccurate, and impoverished ontology. Such an ontology of the self leads to a closing of both the heart and the mind.

\subsection{No-Self, Interconnectedness, and Compassion}

It might appear as though there are few parallels between Taylor's ontology of the self and its implications for ethics and politics, and those of Buddhist views. In fact, the latter might seem quite the opposite: many Buddhist views of the self as no-self, or anātman, appear to be in stark contrast to Taylor's social ontology. This is certainly true when one thinks of various Abhidharma traditions, such as that of Sarvāstivāda and Theravāda schools. According to such schools, the self or the attman understood as a substantial, separate, and permanent individual is a delusion. ${ }^{3}$ Such a self does not exist. On the contrary, the self of everyday is but an

\footnotetext{
${ }^{3}$ There is a widespread and prevalent misconstrual of the Upanișadic notion of atman as being identical with a substance-like eternal individual ego-self, purportedly held by "Hindus" versus the no-self views of Buddhists. No doubt some at the time of the Buddha employed the concept of attman in this way; nevertheless, the concept of âtman is frequently used in many of the Upanișads to refer to exactly the opposite of the self as a substance-like individual ego-self with a unique essence. Rather, attman is used to denote an unconditioned reality, or a pre-reflective form of pure consciousness, which gives rise to the false sense of individual ego-self; indeed, it gives rise to the very ideas of time and space themselves. Time- and space-dependent concepts, such as "eternal" and "substance," strictly speaking, fail to apply to ātman; see e.g., Bṛhadāraṇyaka Upaniṣad 3.4; see also Śankkara's (8th c. CE) later interpretation of àtman (no doubt influenced by Buddhists and sometimes derisively referred to as a crypto-Buddhist). For a contemporary discussion of this issue, see Albahari (2002), Werner (1996), and Lindtner (1999). I should also like to point out that Daisetz Suzuki, the eminent Zen philosopher, does not fall prey to any such misconception and is
} 
aggregate of processes: the five skandhas, consisting of physical/bodily processes and the mental processes of consciousness, perception, emotion, and volition. What we think of as an individual self is simply a way to count things, which can be reduced to their various constituents. This becomes apparent in the Questions of Milinda (approx. 100 BCE) where the philosopher-monk Nāgasena argues in his conversation with Indo-Greek king Milinda, as there is no chariot over and above its constituent parts, there is no self over and above various physical and mental processes. Indeed, the chariot cannot be found in the wheels, the yoke, the axle, the goading-stick, or the banner-staff. It is merely but a "way of counting, term, appellation, convenient designation" (Koller and Koller 1991, 224). Analogously, there is nothing over and above individual parts that we could call a "self." This reasoning extends to all macroscopic entities for most Abhidharmists. Such entities can be reduced to their elemental parts, or momentary dharmas in time and space. We should note that at the microscopic level, such dharmas do have substantial selfexistence (svabhāva) and unique characteristics (svalakșaṇa).

This kind of reductionist view of the self has more in common with current cognitive science (and philosophers such as Derek Parfit or Daniel Dennett) than with Taylor's social ontology and anti-foundationalism. Taylor, in fact, explicitly rejects an almost identical analogy of the self when he denies that the self can be neutralized as a punctum ${ }^{4}$ that can be compared to a car, for there are no comparatively meaningful questions to pose about the identity of a car, which is an assemblage of mechanical parts, in contrast to a self-interpreting being who inhabits the 'space of reasons' - a space of practical and moral considerations - i.e. someone who is an agent, for whom things have purpose and meaning, and for whom things matter $(1989,50)$.

However, these are not the only interpretations of the idea of no-self. In a similar anti-reductionist spirit to Taylor's metaphysics, some Mahāyāna traditions, such as that of the Chinese Hua-Yen school, the Chan/Zen school, and various Tibetan traditions, also interrogate reductive and essentialist interpretations of no-self. Such perspectives resonate with Taylor's views in a number of ways; in particular, the overlapping emphasis on the inter-relationship between self and other lead similarly to a broadening of the scope and domain of ethical and moral concern.

At the heart of various Mahāyāna perspectives and ontologies of the self is the notion of pratītya-samutpāda or interconnectedness (often termed 'dependent origination'), which is associated with the idea of anitya or impermanence, and śünyatā or emptiness. As for Taylor, for Buddhists, the self exists in relation to the good; in the Mahāyāna context, the good is understood as nirvana and awakening for all sentient beings, free from all forms of suffering or duhkha (or dukkha in Pali).

clear on the distinction between ātman construed as unconditioned being versus phenomenal egoself (1900, 106). In addition, see Thompson (2015, 1-20) for a contemporary and insightful reading of some of the principal Upanișads with regard to âtman and consciousness.

${ }^{4}$ N.B. the footnote near the beginning of this chapter, in which this objection is dissociated from those that might be addressed to what Mark Siderits calls 'punctualism', a very different position in philosophy of mind. 
Suffering is a result of not understanding and not coming to terms with the dynamic and connected nature of reality. It is perpetuated by trșna (P. tanha) and upādāna: craving and clinging to a false sense of separate and permanent selfhood. An early formulation of the idea of pratītya-samutpāda was expressed this way:

That being, this comes to be;

From that arising, this arises;

That being absent, this is not;

From the cessation of that, this ceases. (Nidāna Samyutta)

Interconnectedness points to the dynamic and causally connected nature of reality as a process of becoming (rather than being); the claim is that nothing, including the self, can exist by itself. Nothing has permanent and unchanging self-existence/ownbeing or svabhāva or unique essence (svalakșana). Everything is dynamic and causally related. All things and events are dependent on the conditions and causes from which they arise, and when these conditions and causes cease, such things and events too will cease. ${ }^{5}$ Abhidharmists have no issue with this, but they consider the ultimate constituents of causality, the dharmas, to be self-existentially real, which most Mahāyānists deny. The philosopher-monk Nāgārjuna (second century CE), who founded the Madhyamaka or middle way school, contends that all things and events, even dharmas, are śünya or empty of any kind of inherent unchanging selfexistence or unique essence. I read Nāgārjuna's arguments transcendentally: if change and becoming is possible, then there can be no ultimate constituents of conditions and causes that are assumed to have inherent self-existence or unique essence. If conditions and causes were indeed separate individuals with unique essence, then one could not explain their inter-relationship, and hence the possibility of transformation and change (see Nāgārjuna (1986), 105-117). Contemporary Zen master Thich Nhat Hanh explains Nāgārjuna's ideas in terms of the notion of "inter-being":

So what permanent thing is there that we can call a self? ... Nothing can exist by itself alone. It has to depend on every other thing. That is called inter-being. To be means to interbe. The paper inter-is with the sunshine and with the forest. The flower cannot exist by itself alone; it has to inter-be with soil, rain, weeds and insects. There is no being; there is only inter-being. Looking deeply into a flower, we see that the flower is made of non-flower elements. We can describe the flower as being full of everything. There is nothing that is not present in the flower. We see sunshine, we see the rain, we see clouds, we see the earth, and we also see time and space in the flower. A flower, like everything else, is made entirely of non-flower elements. The whole cosmos has come together in order to help the flower manifest herself. The flower is full of everything except one thing: a separate self, a separate identity. The flower cannot be by herself alone. The flower has to inter-be with the sunshine, the clouds and everything in the cosmos. If we understand being in terms of inter-being, then we are much closer to the truth. Inter-being is not being and it is not non-being. Interbeing means being empty of a separate identity, empty of a separate self $(2002,47-48){ }^{6}$

\footnotetext{
${ }^{5}$ For an insightful analysis of the differing and extended sense in which many Buddhist schools use the idea of causation, see Cook 1977, 67-74.

${ }^{6}$ I thank Emily Jull for bringing this passage to my attention.
} 
The Chinese Hua-Yen school of Buddhism describes the inter-related nature of selves in the beautiful metaphor of the jewelled Net of Indra. In the Avatamsaka Sūtra, the existence of selves and the cosmos or suchness (tathātā) is described in terms of an infinite and multi-dimensional net extending in all possible directions, with sparkling and multi-faceted diamonds of "blazing" "boundless" selfilluminating "Golden Light from a Spotless Sun" tied at each juncture or knot of the net (Avatamsaka Sūtra 1984, 226, Cleary translation; see also 212-241). No individual self exists in and by itself; every slight ripple at any one juncture has an effect and reverberation for every other part of the net. Each facet of every diamond in the net reflects every other diamond like a mirror. As Francis Cook explains: the net represents the "infinitely repeated interrelationship among all members of the cosmos" and their "mutual identity and mutual inter-causality" (1977, 2; see also pp. 75-89). Analogous to what we find in Taylor's ontology of the self, there is the notion that the being of 'selves' is interpenetrated and interpenetrating; the self is reflected and mirrored in the lives of significant others and of the community, and of the globe. It is part and parcel of an entirety, of dialogical relationships with which, and to which, one is intrinsically tied. As Taylor would say, one can only be a self among others, intrinsically related to others; an individual always and only takes real shape as a 'self' when in sufficiently close relations with other selves.

What are the implications for ethics of such an ontology of the self? For Taylor, the rejection of an atomistic account of the self as a punctum (conceived of a separate and permanent individual âtman), in favour of a more web-like dialogical view of the self as interconnected to others, has ethical implications that are analogous to those recognized by some Mahāyāna schools. Insight into pratītya-samutpāda leads the philosopher-monk Santideva (8th CE), in his Bodhicāryāvatāra, ${ }^{7}$ to posit the self as a part and parcel of an organic whole, intimately connected to all others. Just as the hand protects the foot (VIII. 99) and the integrity of the body, we should protect other sentient beings.

VII. 90

First, one should earnestly meditate

On the similarity of self and others:

Everyone, subject to similar happiness and suffering

Should be protected by me like myself.

VIII. 91

Just as the body, having many parts, divided into hands etc.,

Should be protected as one.

The world, though divided, is undivided

With respect to the nature of suffering and happiness. (Garfield et al. 2016, 59)

\footnotetext{
${ }^{7}$ See the Cowherds (i.e., Garfield et al. 2016, 54-76) for an illuminating history of this text; like most Indian philosophical texts, some passages may have been added later. Various different translations and readings of these passages depend on the exact nature of one's interpretation of anātman, the self that is the subject of suffering, and its relation to the other. My favoured reading is from a Chan/Zen perspective. See also Edelglass (2017) for an insightful contextualization of Śāntideva's ethics as embedded within a bodhisattva ideal.
} 
Santideva implores us to move beyond the individualistic self-interest that is characteristic of a Hobbesian liberal contractual mentality: dividing the world into an isolated me and a you, forgetting that there is no me without you, nor you without me. The sharp lines drawn by such a picture are misguided, for the suffering of another is like my own suffering. Indeed, I should thus strive to eliminate the suffering of all sentient beings:

VIII. 94

The suffering of others should be eliminated by me,

Because it is suffering like my own suffering.

I should help others

Because they are sentient beings, as I am a sentient being. (59)

It is only when I am in the grip of a false ontology, a false understanding of the reality of the self as a unique and permanent entity that I develop a deep and false sense of I-ness or ahamkāra, which is the cause (and at the same time, the result) of more separation, suffering, and misery in the world (see verse VIII.101, trans. Garfield et al.). This ontology perpetuates a vicious circle of alienation of self from other(s). Such misguided views are grounded in, and at the same time lead to, thinking and feeling that your suffering has no bearing on my own, and that our interests are completely separate. As Śantideva brilliantly argues: "what is so special about me that I merely strive for my own happiness?" (VIII. 95). Is my hunger, pain, and isolation different from yours? Does it not hurt in the same ways? One might try to insist that another's pain is in her body, while my pain is in my own; but would I not feed my child because the hunger is in her body and not in my own? Of course I would feed her, regardless of our differing physical bodies. Our individuation may be separate but our selves are in common, our interests are in common.

Daisetz Suzuki interprets the Awakening of Faith, attributed to Aśvaghoșa (second century $\mathrm{CE})^{8}$ from a Zen perspective in a similar manner. The realization of emptiness of the self as a separate and permanent being, and the attempt to understand the dharmadhātu or the totality of things, or suchness (bhütatathātā or tathātā) at the level of ontology, leads one to broaden one's ethical perspective, broaden and develop a sense of karuña or compassion, and leads one to treat others as their own selves by a principle of equality:

What is meant by the activity of suchness is this: all Buddhas, while at the stage of discipline, feel a deep compassion (mahākarunāa) [for all beings], practice all pāramitās, the four methods of entertainment (catvāri-sangrahavstūni), and many other meritorious deeds; treat others as their self, wish to work out a universal of mankind in ages to come, through limitless number of kalpas; recognize truthfully and adequately the principle of equality (samatā); and do not cling to individual existence of a sentient being. (Suzuki 1900, 98-99)

The Dalai Lama uses almost an identical train of thought to argue that it is a misguided atomistic picture of the self that leads one to ignore others' interests apart from one's own:

\footnotetext{
${ }^{8}$ This attribution to Aśvaghoșa is questionable because - among other reasons - no Sanskrit text has been found; however, the text is an influential work, and I take Suzuki's reading and interpretation as offering legitimate insight into Mahāyāna views of Suchness, śūnyatā, and ethics.
} 
When we come to see that everything we perceive and experience arises as a result of an infinity of dependently originated and interrelated causes and conditions, our whole perspective changes. We begin to see that the universe we inhabit can be understood in terms of a living organism in which each cell works in balance cooperation with every other cell to sustain the whole. If just one of these cells is harmed, as it is when disease strikes, that balance is harmed and there is danger to the whole. This in turn suggests that our individual well-being is intimately connected both with that of all others and with the environment within which we live. It also becomes apparent that our every action, our every deed, word and thought, no matter how slight or in consequential it may seem, has an implication not only for ourselves but for all others too. Furthermore, when we view reality in terms of dependent origination, it draws us away from our usual tendency to see things and events in terms of solid, independent, discrete entities.. .. we come to see that the habitual sharp distinction we make between 'self' and 'others' is itself and exaggeration.. .. it is possible to imagine becoming habituated to an extended conception of self wherein the individual situates his or interests within the interests of others... . If the self had intrinsic identity, it would be possible to speak in terms of self-interest in isolation from that of others. But given that this is not so, given that self and others can only be understood in terms of relationship, we see that the self-interest and the interest of others are similarly interrelated. Indeed, within this picture of dependently originated reality, we see that there is no self-interest completely unrelated to others' interests. Due to the fundamental interconnectedness which lies at the heart of reality, your interest is also my interest.. .. And because, as we have seen, our interest are inextricably linked, we are compelled to accept ethics as the indispensable interface between my desire to be happy and yours (1999, 46-49).

I should again like to note the overlap of the way in which a rejection of the self as a kind of geometric punctum for Taylor, and the rejection of the self as a discrete entity with unique self-existence and essence for various Buddhist schools, leads to a broadening of ethical concern and obligation to and for others. Indeed, there is a growing global convergence here, which ranges across feminist views of the self to deep ecology (see e.g., Naess ${ }^{9}$ 1985) in that the self cannot be severed from the other in a neat surgical fashion, or from the cosmos of which it is a part; or to put this differently, such a feat cannot be accomplished without distortion, and without profound cost and debilitating consequences for ourselves, our communities, and our natural environments. ${ }^{10}$ The overlapping consensus of the chorus of such a challenge to individualist ontologies of the self, as they continue to manifest in economic greed, destruction of natural environments and cruelty to non-human animals, shows the urgency of re-thinking such views, and opening a necessary global, intercultural, and inter-philosophical dialogue and exploration of what is required for a sustainable future for humanity.

I take the purpose of all of these challenges to be that of conceptually widening the circle of our moral concern by chipping away at the false ontology of the self that divides us from the other. The purpose of Buddhist philosophical arguments how-

\footnotetext{
${ }^{9}$ See also the discussion of Naess and deep ecology in the chapter following, by Gordon Davis and Pragati Sahni.

${ }^{10} \mathrm{I}$ argue elsewhere that toleration, as a political phenomenon, apart from being simply an individual virtue, was first constructed by Emperor Aśoka (268-232 BCE) based on Buddhist interpretations of ahims $\bar{a}$ or non-violence long before it was constructed as such in Europe (see Peetush 2015).
} 
ever is not simply intellectual. The philosophical enterprise is conceived not merely as conceptual, but as a contemplative practice (at least, for many schools in India, China, Japan, and Tibet); its aim is to deepen and widen understanding so as to improve lived experience and to lessen suffering in the world. This is one reason that a practice such as mindfulness, dhyāna or zazen, may be intrinsic to such an enterprise. Philosophy cannot be neatly isolated from practice, as most modern Western philosophers would have it. Indeed, to paraphrase Marx, the purpose of philosophy is not simply to interpret the world, but (also) to change and transform it.

While one might grant that, in broad strokes, the logic of interrogating ontologies of atomistic accounts of selves as separate, unchanging, and disconnected entities lead both Taylor and Buddhists, and indeed many others, to broaden the scope and domain of the ethical, there are admittedly some deep dissimilarities that I have set aside here. Buddhist notions of self and interconnectedness, the Net of Indra, and emptiness, are ontologies and concerns about the ultimate basis of the real, the dharmadātu, the totality of being and our place in it. Their aim is to get behind conventional truth, to get behind our phenomenal existence, to the underlying reality that exists behind the world of appearance or samsāra. One might object that there is a contrast here with Taylor, who is a realist of a different kind. For him, there is no reality that is somehow more real than the one we experience now. For many Buddhists however, the everyday self and world reflect $m \bar{a} y \bar{a}$, or illusion. Of course, we might deceive ourselves about our real motivations (or have false sense impressions, etc.), as Taylor would admit, but this is not the same sense of deception, in degree or kind, that these Buddhists would posit. Even Taylor's belief in God would, presumably, be of a divine source standing in a benevolent relationship to our world, a world of His own creation. In fact, Taylor says little about the nature of the soul as providing a defining feature of the ontology of selfhood. Taylor's ontology of the self is but a social ontology with the potential to correct complex and sophisticated fabrications and distortions that have arisen in the West, which need to be exposed as misguided and false - distortions that have the potential to lead to the fragmentation and demise of flourishing democratic regimes, but nothing more. My analysis, some will thus say, glosses over this critical difference.

In response, I want to reemphasize that for Taylor, the dialogical nature of the self is an ontological feature of selfhood. This characteristic is not merely a historical, social, and political contingency, as some might take Taylor to be saying. Furthermore, and as importantly, that such a self can only be understood teleologically in relation to the good - a self-interpreting being for whom things have significance, meaning, and purpose - is also an ontological feature of selfhood. For Taylor, the best possible explanation of such meaning and significance is that these are part and parcel of the intersubjective ontological furniture of the real world. It may be that, if beings like us ceased to exist, the good would also cease to exist; nonetheless, the good is not merely a projection on to the world, according to Taylor; it is not a "subjective" property mapped onto a neutral cosmos (2003). This general conception of a middle way bears some resemblance to the ontological orientation of various Buddhist schools.

Secondly, while I certainly agree that some Buddhist schools adopt an anti-realist and reductionist stance towards the phenomenal self and world, it is far from accu- 
rate to claim that these are representative of all Buddhist views. Indeed, many of the Tibetan and Zen schools reject the idea that we can somehow ignore the phenomenal world as simply illusory. What is required is not a repudiation of our shared common-sense world, but a transformation of how we come to see this world, and the place of our selves in it; the aim is to break through the distortion of separateness; and this is much like Taylor's view. As the Dalai Lama remarks:

... while acknowledging that there is often a discrepancy between perception and reality, it is important not to go to the extreme of assuming that behind the phenomenal is a realm which is somehow more 'real'. The problem with this is that we may then dismiss everyday experience as nothing but an illusion. This would be quite wrong. Similarly, accepting a more complex understanding of reality, in which all things and events are seen to be interdependent, does not mean we cannot infer that the ethical principles we identified earlier cannot be understood as binding. $(1999,48)$

Dependent origination and the emptiness of self-existence, on this interpretation, is not meant to undermine the reality of our everyday lives, but to provide a more perspicuous framework in which to locate ourselves and others:

Far from undermining the notion of phenomenal reality, the concept of dependent origination provides a robust framework within which to situate cause and effect, truth and falsity, identity and difference, harm and benefit. It is therefore quite wrong to infer from the idea any sort of nihilistic approach to reality. $(1999,45)$

Indeed, nirvana is not separate from samsāra, as the practice of emptiness and Zen (among other schools) teach; it is attained by fully living and being present in the moment: in washing your dishes, sweeping the floor, eating breakfast, listening to your daughter or son, and talking with a friend. ${ }^{11}$ Nirvana is not an otherworldly heaven, it exists in the here and the now; it is the lived experience of the interrelatedness of the web of life or the Net of Indra. Compassion awakens one to such interconnection and, at the same time, is rooted in such interconnection; it is nothing if only in the mind and the intellect. It has to be in the heart, in the act, and in the daily practice of relating oneself to others. None of this is to deny the various differences between the ontologies of the self found in Taylor and Buddhism (nor, to be sure, those among Buddhist schools themselves). My point is that some of these differences may not be as deep or as wide as they may at first appear. Indeed, such ontologies of the self, and their ethical implications, are complementary in significant respects.

\footnotetext{
${ }^{11}$ Daisetz Suzuki utilizes R.H. Blyth's reading of Bashō's haiku in a similar regard:

Fleas, lice,

The horse pissing

Near my pillow

- Bashō
}

We are urged to understand that "these things too," the fleas, the lice, the horse urinating, as well as "butterflies," are an intimate part of the real, a part of what it is to live in the real world, a part that cannot simply be dismissed in favor of some heavenly realm (Suzuki 1973, 237-238; see also Cook 1977, 11). 


\section{References}

Albahari, Miri. 2002. Against No-Ātman Theories of Anattā. Asian Philosophy 12 (1): 5-20.

Cleary, Thomas. 1984. The Flower Ornament Scripture: A Translation of the Avatamsaka Sutra. Boulder: Shambhala Publications.

Cook, Francis. 1977. Hua-Yen Buddhism: The Jewel Net of Indra. New York: Pennsylvania State University.

Edelglass, William. 2017. Mindfulness and moral transformation: Awakening to others in Sāntideva's ethics. In The Bloomsbury Research Handbook of Indian Ethics, ed. S. Ranganathan, 225-248. New York: Bloomsbury Press.

Garfield, Jay, Stephen Jenkins, and Graham Priest. 2016. The Śantideva Passage: Bodhicāryāvatāra VII.90-103, 55. In Moonpaths: Ethics and Emptiness, ed. Cowherds. New York: Oxford University Press.

Gyatso, Tenzin. (His Holiness the Dalai Lama). 1999. Ancient Wisdom, Modern World: Ethics for a New Millennium. London: Little, Brown and Company.

Koller, John, and Patricia Koller. 1991. A Sourcebook in Asian Philosophy. Upper Saddle River: Prentice Hall.

Lindtner, Christian. 1999. From Brahmanism to Buddhism. Asian Philosophy 9 (1): 5-37.

Naess, Arne. 1985. The World of Concrete Contents. The Trumpeter 22 (1): 43-55.

Nāgārjuna. 1986. Nāgārjuna: The Philosophy of the Middle Way. Trans. D. Kalupahana. New York: State University of New York Press.

Nhat Hanh, Thich. 2002. No Death, No Fear: Comforting Wisdom for Life. New York: Riverhead Books.

Nozick, Robert. 1974. Anarchy, State, and Utopia. New York: Basic Books.

Nussbaum, Martha. 2006. Frontiers of Justice: Disability, Nationality, Species Membership. Cambridge, MA: Harvard University Press.

Peetush, Ashwani. 2015. Human rights and political toleration in India: Multiplicity, self, and interconnectedness. In Human rights: India and the West, ed. A. Peetush and Jay Drydyk, 205-228. New Delhi: Oxford University Press.

Rawls, John. 1999. A Theory of Justice. Cambridge, MA: Belknap Press.

Sandel, Michael. 1995. Liberalism and the Limits of Justice. New York: Cambridge University Press.

Suzuki, Daisetz [Teitaro]. 1900. Açvaghosha's Discourse on the Awakening of Faith in the Mahâyâna. Chicago: The Open Court Publishing Company.

— [Teitaro]. 1973. Zen and Japanese Culture. New York: Princeton University Press.

Taylor, Charles. 1985a. The Concept of a Person. In Philosophy and the Human Sciences: Philosophical Papers 2, 58-90. New York: Cambridge University Press.

- 1985b. Neutrality in Political Science. In Philosophy and the Human Sciences: Philosophical Papers 2, 58-90. New York: Cambridge University Press.

- 1985c. What's Wrong with Negative Liberty. In Philosophy and the Human Sciences: Philosophical Papers 2, 211-229. New York: Cambridge University Press.

. 1985d. Atomism. In Philosophy and the Human Sciences: Philosophical Papers 2, 187210. New York: Cambridge University Press.

- 1989. Sources of the Self: The Making of the Modern Identity. Cambridge, MA: Harvard University Press.

-1993. Reconciling the Solitudes: Essays on Canadian Federalism and Nationalism, ed. Guy Laforest. Montreal: McGill-Queen's University Press.

- 1995a. Cross-Purposes: The Liberal-Communitarian Debate. In Philosophical Arguments, 181-203. Cambridge, MA: Harvard University Press.

- 1995b. Irreducibly Social Goods. In Philosophical Arguments, 127-145. Cambridge, MA: Harvard University Press.

- 1995c. The Politics of Recognition. In Philosophical Arguments, 225-256. Cambridge, MA: Harvard University Press. 
. 1999. Conditions of an Unforced Consensus on Human Rights. In The East Asian Challenge for Human Rights, ed. Joanne R. Bauer and Daniel A. Bell, 124-144. New York: Cambridge University Press.

2003. Ethics and Ontology. The Journal of Philosophy 100 (6): 305-320.

Thompson, Evan. 2015. Waking, Dreaming, and Being. New York: Columbia University Press.

Werner, Karel. 1996. Indian Conceptions of Human Personality in Relation to the Doctrine of the Soul. Journal of the Royal Asiatic Society of Great Britain and Ireland 1: 73-97. 